\section{Light Activation and Thermocycling Methods on the Shear Bond Strength of Brackets Bonded to Porcelain Surfaces}

Gustavo Vallandro Lopes $^{1}{ }^{\circ}$, Lourenço Correr-Sobrinho ${ }^{2} \oplus$, Américo Bortolazzo Correr ${ }^{2} @$, Ana Paula Terossi de Godoi ${ }^{\circledR}{ }^{\circ}$, Silvia Amélia Scudeler Vedovello ${ }^{1}$, Carolina Carmo de Menezes ${ }^{1}[0$

\author{
'Departament of Orthodontics, Centro \\ Universitário da Fundação Hermínio \\ Ometto-FHO, Araras, SP, Brazil \\ ${ }^{2}$ Departamento of Restorative \\ Dentistry, Dental Materials, \\ UNICAMP - Universidade Estadual \\ de Campinas, Piracicaba, SP, Brazil \\ Correspondence: Carolina Carmo \\ de Menezes, Avenida Maximiliano \\ Baruto, 500, 13607-339 Araras, SP, \\ Brasil. Tel: +55-19-3543-1423.e-mail: \\ carol.menezes.odonto@gmail.com
}

\begin{abstract}
The present study was evaluated the effect of different light activation and thermocycling methods on the shear bond strength (SBS) and on the adhesive remnant index (ARI) of metal brackets bonded to feldspathic ceramic. Hundred metal brackets were bonded to 20 porcelain cylinders, divided into four groups $(n=25)$ based on light activation and thermocycling processes. The cylinders were etched with 10\% hydrofluoric acid for 60 $s$ and coated with two layers of silane. The brackets were bonded with Transbond XT composite resin. Light activation in Groups 1 and 3 was performed during $3 \mathrm{~s}$ using the VALO Ortho Cordless appliance with irradiance $3,200 \mathrm{~mW} / \mathrm{cm}^{2}$ and in Groups 2 and 4 for 40 s using Optilight Max appliance with irradiance 1,200 mW/cm². The samples were stored in deionized water at $37^{\circ} \mathrm{C}$ for $24 \mathrm{~h}$ and the samples from Groups 1 and 2 were submitted to the SBS test at a rate of $1 \mathrm{~mm} / \mathrm{min}$, whereas the samples from Groups 3 and 4 were submitted to 7,000 thermal cycles $\left(5 \% 55^{\circ} \mathrm{C}\right)$ before to the SBS test. The data were assessed by two-way analysis of variance and by Tukey's test $(\alpha=0.05)$. No significant difference was observed between SBS means in the different light activation devices used. The samples subjected to thermocycling revealed lower SBS values $(p \leq 0.05)$. There was predominance of score 0 for $A R I$ in all groups. Therefore, the different light activation methods did not interfere in SBS, but thermocycling reduced SBS.
\end{abstract}

Key Words: ceramic, brackets, light activation, thermocycling.

\section{Introduction}

There has been a growing demand for orthodontic treatment from adult patients (1-3). Quite often, these patients already have porcelain prostheses and they would not like to have them replaced. This attitude urges orthodontists to find bonding alternatives that are effective and harmless to the porcelain $(1,3,4)$.

Different methods have been used to treat porcelain surfaces before bracket bonding so as to increase shear strength, thereby improving clinical bonding efficiency $(4,5)$. According to the literature, application of hydrofluoric acid and silane prior to bracket bonding is the best alternative for preparation of ceramic surfaces (2-4).

Light cured resins have been developed as bracket bonding material, representing major breakthroughs in orthodontics by improving bracket positioning, increasing working time, and facilitating removal of excess material during bonding (6). The first light activation devices consisted of 300 to $400 \mathrm{~mW} / \mathrm{cm}^{2}$ halogen lamps (7). Some alternatives included light-emitting diodes (LED) and plasma arcs, with energy emission at $1,600 \mathrm{~mW} / \mathrm{cm}^{2}$ and $2,000 \mathrm{~mW} / \mathrm{cm}^{2}$, respectively, reducing light activation time (7). Even though there is no clear evidence regarding differences in bonding failure in the three light activation systems, most studies highlight the remarkable reduction in activation time when plasma arcs and LED are used, instead of halogen lamps, for bonding of the brackets to dental surfaces (7-9).

It has been recently corroborated that bonding with shorter activation time maximizes working time and improves the quality of dental services (10). The VALO Ortho Cordless (Ultradent Products, South Jordan, Utah, USA), with three curing modalities, including a high-irradiance mode $\left(3,200 \mathrm{~mW} / \mathrm{cm}^{2}\right)$ and an activation time of $3 \mathrm{~s}(10-12)$, proved to be efficient for bracket bonding (10). However, it is unknown whether this efficiency is the same for different bonding surfaces, because of light reflectance and absorbance of porcelain surfaces, for instance (9). No articles were found in the literature that evaluated the bonding of metal brackets to the porcelain surface with photoactivation time of $3 \mathrm{~s}$ as in the present study.

Efficient bracket bonding to different surfaces may be influenced by thermal changes in the oral cavity (13). Temperature oscillations may cause stress in light activated bonding materials and may interfere with adhesion as a result of the continuous action of water by means of hydrolytic degradation $(3,13)$. Thus, thermocycling should be evaluated in research studies on the efficiency of bracket 
bonding.

As pointed out in the literature, it is important to investigate methods that may reduce the clinical time necessary for the bonding of orthodontic appliances (7), rendering the procedure quicker and more comfortable to the patient and optimizing the orthodontist's clinical practice without damaging the existing prostheses, in addition to maintaining bonding efficiency. Therefore, the aim of this study was to assess shear bond strength (SBS) of metal brackets bonded to feldspathic ceramic and adhesive remnant index (ARI) at different time points ( $40 \mathrm{~s}$ and $3 \mathrm{~s}$ ) and different irradiance levels $\left(1,200 \mathrm{~mW} / \mathrm{cm}^{2}\right.$ and 3,200 $\mathrm{mW} / \mathrm{cm}^{2}$ ) during light activation, either in the presence or absence of thermocycling. The following hypotheses were tested: 1- No statistical difference would be observed between the two LED sources at different irradiance levels and different activation times; 2- Thermocycling would not influence SBS and ARI.

\section{Material and Methods}

Sample

The sample in this in vitro experimental study consisted of 20 cylinders of feldspathic porcelain (Certec Advanced Ceramics, Barueri, SP, Brazil) measuring $19 \mathrm{~mm}$ in height and $12 \mathrm{~mm}$ in diameter. The porcelain cylinders were cleaned by previous prophylaxis with pumice stone (S.S. White, Petropolis, RJ, Brazil) and a rubber cup (KG Sorensen, Cotia, SP, Brazil). Thereafter, each cylinder was etched with 10\% hydrofluoric acid (Dentsply do Brasil, Petrópolis, Rio de Janeiro, Brazil) for 1 min following the gold standard in the preparation of the porcelain as already described in previous studies $(3,4,14)$ and later washed with water jets for $30 \mathrm{~s}$ and air-dried for $30 \mathrm{~s}$. Two layers of Silane RelyX Ceramic Primer (3M ESPE - Saint Paul, MN, USA) were subsequently applied with a microbrush (KG Sorensen, Cotia, São Paulo, Brazil) for $60 \mathrm{~s}$ and then left to dry for $10 \mathrm{~s}$ between applications (14).

A total of 100 metal brackets for lower premolars (Abzil; 3M do Brasil Ltda, São José do Rio Preto, SP, Brazil) were bonded to the cylinders (five brackets per cylinder) using Transbond XT (3M Unitek, Monrovia, CO, USA). A layer of the adhesive material was applied to the porcelain, and composite resin was applied to the bracket base, according to the manufacturer's instructions (3). After the brackets were bonded, excess bonding material was removed with a microbrush (KG Sorensen, Cotia, São Paulo, Brazil) (14).

\section{Photoactivation Procedures}

Two devices were used for light activation of the bonding system: Optilight Max (Gnatus Equipamentos Médicos e Odontológicos, Ribeirão Preto São Paulo, Brazil) - 1,200 mW/ $\mathrm{cm}^{2}$ power; and VALO Ortho Cordless
(Ultradent Products, South Jordan, Utah, USA) - 3,200 mW/ $\mathrm{cm}^{2}$ power. Five brackets were bonded to each cylinder and split into groups according to light activation and thermocycling.

Groups 1 and 3 were light activated for $3 \mathrm{~s}$ on the occlusal surface of each bracket using VALO Ortho Cordless (Ultradent Products, South Jordan, Utah, USA) at maximum power $\left(3,200 \mathrm{~m} \mathrm{~W} / \mathrm{cm}^{2}\right)$, whereas Groups 2 and 4 were light activated for $40 \mathrm{~s}$ (10 s for each bracket surface: mesial, cervical, distal, and occlusal) using Optilight Max (Gnatus Equipamentos Médicos e Odontológicos, Ribeirão Preto São Paulo, Brazil) at the power of $1,200 \mathrm{~mW} / \mathrm{cm}^{2}$. The power of both photopolymers was checked by a power meter (Ophir Optronics Inc, Danvers, MA, USA). Radiation exposure was $9.6 \mathrm{~J} / \mathrm{cm}^{2}$ and $48 \mathrm{~J} / \mathrm{cm}^{2}$ for Valo and Optilight Max, respectively, calculated according to Beolchi (11) and Sword (15).

To prevent brackets bonded to the cylinder from being exposed to photopolymerization light, the black adhesive tape technique was used, following the standard method described in the literature $(3,4,16)$ (Fig. 1).

\section{Thermocycling}

After bonding, all cylinders were stored in deionized water at $37^{\circ} \mathrm{C}$ for $24 \mathrm{~h}$ in an oven (Fanem LTDA-São Paulo, SP, Brazil). Cylinders in Groups 1 and 2 were subjected to the SBS test, whereas cylinders in Groups 3 and 4 were subjected to 7,000 thermal cycles (MSCT 3, Marnucci ME, Sao Carlos, SP, Brazil) using deionized water at 5 and $55^{\circ} \mathrm{C}$

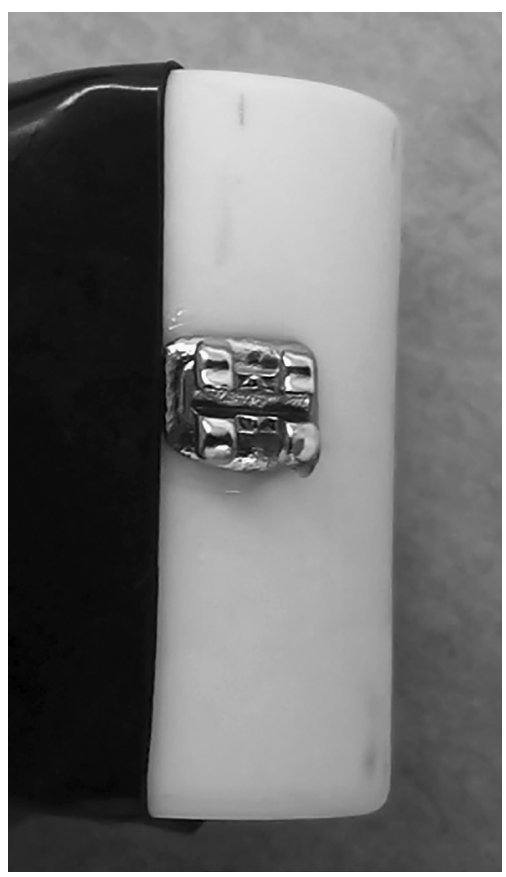

Figure 1. Coverage of brackets bonded with black adhesive tape. Black adhesive tape technique $(3,4,16)$. 
(30 s per bath and a 10-s interval between baths), (3) and later subjected to the shear strength test.

\section{SBS test}

The SBS of brackets to the ceramic surface was assessed by a universal testing machine (Model 4411; Instron, Canton, MA, USA) at the speed of $1 \mathrm{~mm} / \mathrm{min}$. The machine's chisel was positioned parallel to the ceramicbracket interface $(3,4,16)$. Shear forces were measured in $\mathrm{kgf} / \mathrm{cm}^{2}$ and converted to MPa.

\section{Adhesive Remnant Index (ARI)}

After bracket debonding, the porcelain surfaces were examined with a magnifying glass (ICEL TL 1106, Manaus, AM, Brazil), 10x magnification, to calculate the ARI, based on the method of Artun and Bergland (17), as follows: Score 0: no bonding residue on the ceramic surface; Score 1 : less than $50 \%$ of the bonding material remained on the ceramic surface; Score 2: more than 50\% of the bonding material remained on the ceramic surface; and Score 3: all of the bonding material remained on the ceramic surface.

\section{Statistical Analysis}

SBS data were assessed by two-way ANOVA and by Tukey's test using a $5 \%$ significance level $(\alpha=0.05)$. The statistical analysis was performed with SPSS 13.0 (SPSS Inc, Chicago, IL, USA).

\section{Results}

Shear bond strength values were significantly lower for samples subjected to thermocycling $(p<0.00001)$, but no significant difference was observed among the different light activation devices $(p=0.13370)$. There was no significant difference between thermocycling and light source interactions $(\mathrm{p}=0.81766)$. The mean shear strength values are shown in Table 1.

There was predominance of score 0 for $A R I$ in all groups (Table 2).

Table 1. Mean shear bond strength (MPa) and standard deviation of brackets bonded to ceramic in samples subjected or not to thermocycling (TC), light activated with Optilight Max and VALOOrtho Cordless

\begin{tabular}{lcc}
\hline & Optilight Max & Valo-Ortho Cordless \\
\hline $\begin{array}{l}\text { Without } \\
\text { thermocycling }\end{array}$ & $7.4( \pm 0.9) \mathrm{Aa}$ & $7.0( \pm 1.1) \mathrm{Aa}$ \\
$\begin{array}{l}\text { With TC } \\
\text { thermocycling }\end{array}$ & $4.4( \pm 0.2) \mathrm{Ab}$ & $3.8( \pm 0.1) \mathrm{Ab}$ \\
\hline
\end{tabular}

Identical upper-case letters on the line are not statistically different for light sources ( $p>0.05)$. Means followed by different lower-case letters in the column indicate significant difference between groups subjected and not subjected to thermocycling $(\mathrm{p}<0.05)$.

\section{Discussion}

Successful bonding of metal brackets to porcelain surfaces and their durability are influenced by several factors, such as preparation of porcelain surfaces, quality of bonding agents, photopolymerization process, and fatigue of bonding agents simulated by means of thermocycling (3-5). The preparation of the ceramic surface is an important step. For proper bonding to the ceramic, the surface is usually etching with hydrofluoric acid $(3,4,14,16)$. Recurrent clinical condition when prosthetic ceramic elements are present and orthodontic brackets must be fixed to the ceramic surface. Hidrofluoric acid is known as the responsible for creating a rough surface and increasing the contact surface area in the ceramic bonding area, improving the interation between bonding material and ceramic (16). Thus, this procedure is performed have found to be the most efficient method of orthodontic bonding. However, due to the harmful effects of hydrofluoric acid, the clinician should be careful during its clinical application (4).

The present study assessed the effects of different light activation methods and of thermocycling on the shear strength of metal brackets bonded to porcelain surfaces. The first hypothesis that light sources would not change the shear strength of metal brackets bonded to porcelain surfaces was confirmed, since no statistically significant differences were found between the different light activation sources at different time periods and power levels. This finding is in line with those described in the literature, which has not shown significant differences in light activation sources and time regarding the bonding of brackets to different surfaces, such as bovine enamel, human enamel, and porcelain, even though the light activation sources are not the same $(4,6,7,12,18,19)$. $0 z$ et al.(10) assessed LED sources using similar light activation time to the one used herein and they did not find statistically significant differences, but they observed shear strength in metal brackets bonded to extracted human premolars and not in ceramic surfaces.

Irradiance or light intensity $\left(\mathrm{mW} / \mathrm{cm}^{2}\right)$ is an important parameter that should be assessed in photopolymerization. The concept of total energy demonstrates that the

Table 2. Fracture pattern of ARI samples (\%) for the different light sources, subjected or not to thermocycling

\begin{tabular}{lccccc}
\hline \multirow{2}{*}{ Light Source } & Thermocycling & \multicolumn{4}{c}{ ARI scores (\%) } \\
\cline { 3 - 6 } & Without & 92 & 4 & - & 4 \\
\hline Valo-Ortho & Without & 96 & 4 & - & - \\
Optilight Max & With & 100 & - & - & - \\
Valo-Ortho & With & 100 & - & - & - \\
Optilight Max & & & &
\end{tabular}

ARI: Adhesive remnant index. 
photopolymerization process depends on the energy taken up by the resin, in which irradiance is multiplied by exposure time (15). Previous studies have argued that irradiance should range from 6 to $16 \mathrm{~J} / \mathrm{cm}^{2}$ to be effective, but these values are not absolute as they depend on other factors such as type, thickness, and translucency of the resin and on the type of photoinitiator $(11,15)$. In the present study, exposure to radiation was $9.6 \mathrm{~J} / \mathrm{cm}^{2}$ for light activation with VALO Ortho Cordless and $48 \mathrm{~J} / \mathrm{cm}^{2}$ for light activation with Optilight Max. The difference was not enough to change SBS, though. In line with the findings of the present study, some studies have suggested that the extremely thin layer of resin with no need for deep light activation used for bracket bonding would cancel out the effect associated with the difference in energy uptake, which, by itself, would not be enough to change SBS. In addition, the wavelengths of LED devices would efficiently stimulate camphorquinone, rendering photopolymerization effective, regardless of the difference in energy uptake $(4,11)$.

The second hypothesis tested in the present study that thermocycling would not influence shear strength was rejected. Thermocycling has been used to simulate fluctuations in temperature and moisture in the oral environment in order to assess their influence on shear strength $(3,13,20,21)$. The reduction of the mechanical properties of bonding resins might be caused by the continuous action of water in hydrolytic degradation or by the difference in the coefficient of expansion among brackets, bonding resin, and ceramic (22). There were statistically significant differences in the presence of thermocycling, regardless of the LED used.

Consistent with the present manuscript, several studies have demonstrated that thermocycling has a significant effect, reducing SBS $(3,23,24)$. However, some other studies did not find significant differences in bond strength in the presence of thermocycling $(13,25)$, possibly due to the use of a smaller number of thermal cycles in such studies, when compared to 7,000 cycles suggested to simulate the oral environment and a longer orthodontic treatment period, around 5.83 years (24), used in the present study.

ARI predominantly had score 0 in most samples, in line with the findings of previous studies $(3,23,24)$. In the groups subjected to thermocycling, all samples (100\%) had score 0 (with no remnant resin on the porcelain surface), that is, total removal of the resin adjacent to the bracket during shear stress, showing that bonding proved to be weak between the resin and the porcelain. The clinical advantage of that is the reduced need for removal of the resin from the porcelain surface. However, score 3 , in which all resin would remain bonded to the porcelain, would be safer, preventing possible fractures on the porcelain surface during shear stress (16). In this study, the presence of flaws on the porcelain surface was not assessed. Therefore, new hypotheses, which associate the characteristics of this surface with the analyzed variables, are suggested.

Future studies should look into other factors such as light activation distance and angle in order to investigate possible variables that could influence the bonding of metal brackets to porcelain in shorter light activation periods, but thermocycling should be indicated for all factors being evaluated. The present study revealed that different light activation methods did not play a decisive role in SBS of metal brackets to ceramic, but thermocycling reduced shear bond strength.

\section{Resumo}

No presente estudo foi avaliado o efeito de diferentes métodos de fotoativação e ciclagem térmica na resistência da união ao cisalhamento (RUC) e no índice de remanescente adesivo (IRA) de braquetes metálicos colados à cerâmica feldspática. Cem braquetes metálicos foram colados em 20 cilindros de porcelana, divididos em 4 grupos $(n=25)$ de acordo com o processo de fotoativação e ciclagem térmica. Os cilindros foram condicionados com ácido fluoridrico $10 \%$ por 60 s e receberam 2 camadas de silano. Os braquetes foram colados com a resina composta Transbond XT. A fotoativação nos Grupos 1 e 3 foi realizada por 3 segundos usando o aparelho VALO Ortho Cordless com irradiância de $3200 \mathrm{~mW} / \mathrm{cm}^{2}$ e nos Grupos 2 e 4 por 40 segundos utilizando o aparelho Optilight Max com irradiância de $1200 \mathrm{~mW} / \mathrm{cm}^{2}$. As amostras foram armazenadas em água deionizada a $37^{\circ} \mathrm{C}$ por $24 \mathrm{~h}$, após as amostras dos grupos 1 e 2 foram submetidos ao teste de RUC, velocidade de $1 \mathrm{~mm} / \mathrm{min}$, e as amostras dos grupos 3 e 4 foram submetidas a 7.000 ciclos térmicos $\left(5^{\circ} / 55^{\circ} \mathrm{C}\right)$ antes da RUC. Os dados foram submetidos à Análise de Variância dois fatores e ao teste de Tukey $(\alpha=0,05)$. Não foi encontrada diferença significativa entre as médias da RUC nos diferentes aparelhos de fotoativação. Quando submetidos à ciclagem térmica apresentaram menores valores de RUC $(p \leq 0,05)$. 0 IRA mostrou predominância de escore 0 para todos os grupos. Conclui-se que os diferentes métodos de fotoativação não interferiram na RUC, porém a ciclagem térmica reduziu a RUC.

\section{References}

1. Nattrass C, Sandy JR. Adult orthodontics- a review. Br J. Orthod 1995;22:331-337.

2. Gillis J, Redlich M. The effect of different porcelain conditioning techniques on shear bond strength of stainless steel brackets. Am J Orthod Dentofacial Orthop 1998;114:387-392.

3. Abreu Neto HF, Costa AR, Correr AB, Vedovello AS, Valdrighi HC, Santos $E C$, et al. Influence of Light Source Thermocycling and Silane on the Shear Bond Strength of Metallic Brackets to Ceramic. Braz Dent J 2015;26:685-688.

4. Gonçalves PRA, Moraes RR, Costa AR, Correr AB, Nover PRA, Sinhoreti $M A C$, et al. Effect of Etching Time and Light Source on the Bond Strength of Metallic Brackets to Ceramic. Braz Dent J 2011;22:245-248.

5. Aksakalli S, Ileri Z, Yavuz T, Malkoc MA, Ozturk N. Porcelain laminate veneer conditioning for orthodontic bonding: SEM-EDX analysis. Laser Med Sci 2015;30:1829-1834.

6. Sfondrini MF, Cacciafesta V, Pistorio A, Sfondrini G. Effects of conventional and high-intensity lightcuring on enamel shear bond strength of composite resin and resin-modified glass-ionomer. Am J of Orthod Dentofacial Orthop 2001;119:30-35.

7. Fleming PS, Eliades $T$, Katsaros $C$, Pandisd N. Curing lights for orthodontic bonding: A systematic review and meta-analysis. Am J Orthod Dentofacial Orthop 2013;143:92-103

8. Krishnaswamy NR, Sunitha C. Light-emitting diode vs halogen light curing of orthodontic brackets: a 15-month clinical study of bond failures.Am J Orthod Dentofacial Orthop 2007;132:518-523. 
9. Watanabe $H$, Kazama $R$, Kanaya TAF, Ishizaki $H$, Fukushima M, Okiji T. Efficiency of dual-cured resin cement polymerization induced by high-intensity led curing units through ceramic material. Operative Dentistry 2015;40-2:153-162.

10. $\mathrm{Oz} \mathrm{AA}, \mathrm{Oz} \mathrm{AZ}$, Aricib $\mathrm{S}$. In-vitro bond strengths and clinical failure rates of metal brackets bonded with different light-emitting diode units and curing times. Am J Orthod Dentofacial Orthop 2016;149:212-216

11. Beolchi RS, Moura-Netto C, Palo RM, Torres CRG, Pelissier B. Changes in irradiance and energy density in relation to different curing distances. Braz Oral Res 2015;29:1-7.

12. Faria-e-Silva AL, Covell Jr DA, Ferracane JL, Pfeifer CS. Effectiveness of high irradiance for short-time exposures on polymerization of composite under metal brackets. Angle Orthodontist 2017;87:834-840.

13. Bishara SE, Ostby AW, Laffoon J F, Warren J. Shear Bond Strength Comparison of Two Adhesive Systems Following Thermocycling. Angle Orthodontist 2007;77:337-341.

14. Costa AR, Correr AB, Consani S, Giorgi MCC, Vedovello SA, Vedovello Filho $M$ et al. Influence of Water Storage and Bonding Material on Bond Strength of Metallic Brackets to Ceramic. Braz Dent J 2015;26:503-506.

15. Sword RJ, Ngoc Do U, Hu Chang J, Rueggeberg FA. Effect of Curing Light Barriers and Light Types on Radiant Exposure and Composite Conversion. J Esthet Restor Dent 2016;28:29-42.

16. Costa $A R$, Correr $A B$, Puppin-Rontani RM, Vedovello AS, Valdrighi $\mathrm{HC}$, Correr-Sobrinho L et al. Effect of Bonding Material, Etching Time and Silane on the Bond Strength of Metallic Orthodontic Brackets to Ceramic. Braz Dent J 2012;23:223-227.

17. Artun J, Bergland S. Clinical trials with crystal growth conditioning as an alternative to acid-etch enamel pretreatment. Am J Orthod 1984;85:333-340.
18. Lamper T, Steinhäuser-Andresen S, Huth KC, Ilie N ,Paschos E. Does a reduction of polymerization time and bonding steps affect the bond strength of brackets? Clin Oral Invest 2012;16:665-671.

19. Lee HM, Kim SC, Kang KH, Chang NY. Comparison of the bonding strengths of second- and third-generation light-emitting diode lightcuring units. Korean J Orthod. 2016;46: 364-371.

20. Gale MS, Darvell BW. Thermal cycling procedures for laboratory testing of dental restorations. Journal of Dentistry 1999;27:89-99.

21. Guarda GB, Correr AB, Gonçalves $L S$, Costa AR, Borges GA, Sinhoreti MAC et al. Effects of Surface Treatments, Thermocycling, and Cyclic Loading on the Bond Strength of a Resin Cement Bonded to a Lithium Disilicate Glass Ceramic. Operative Dentistry 2013;38:208-217.

22. De Munck J, Landuyt KV, Peumans M, Poitevin $A$, Lambrechts $P$, Braem $M$ et al. A critical review of the durability of adhesion to tooth tissue: methods and results. J Dent Res 2005;84:118-132.

23. Fraga PF, Terossi de Godoi AP, Costa AR, Correr-Sobrinho L, Vedovello Filho $\mathrm{M}$, Valdrighi HC. Influence of adhesive and thermal cycling on the bond strength of ceramic brackets to dental ceramic. Braz J Oral Sci 2017;28:206-209.

24. Jurubeba JEP, Costa $A R$, Correr-Sobrinho $L$, Tubel CAM, Correr $A B$, Vedovello $S A$ et al. Influence of thermal cycles number on bond strength of metallic brackets to ceramic. Braz Dent J 2017;28:206-209.

25. Yuasa T, lijima M, Ito S, Muguruma T, Saito T, Mizoguchi I. Effects of long-term storage and thermocycling on bond strength of two selfetching primer adhesive systems. Eur J Orthod 2010;32:285-290.

Received August 6, 2019 Accepted September 25, 2019 